\title{
ANALYSIS OF FACTORS-FACTORS FECTING THE PERFORMANCE OF ACCOUNTING INFORMATION SYSTEMS IN. BPR SHINTA PUTRA PENGASIH KULON PROGO
}

\author{
Fauzi Kurniawan \\ Moch Imron
}

\begin{abstract}
This study aims to examine the influence of user participation, user personal techniques, training and education as well as management support on the performance of accounting information systems at PT. BPR Shinta Putra Pengasih. The samples in this study were all employees of PT. BPR Shinta Putra Pengasih working section of marketing, human resources, planning, administration and reporting, and the public. The sample selection was based on purposive sampling by distributing questionnaires. The analysis model used is multiple linear regression. The results show that management support and training and education programs for employees does not affect the performance of accounting information systems, in this case can be seen at a significance level above 0.05 is equal to 0.407 and 0.126. While the personal techniques and user participation affect the performance of accounting information systems, it can be seen from the significant value for the variable and value engineering 0,045 personal significance for variable user participation 0.016. That means the value of the personal significance of variables technique and user participation below 0.05. So the higher the personal techniques and user participation, then the information system performance will increase.
\end{abstract}

Keywords: Top management support, training and education programs, personal techniques, user participation, and performance of accounting information systems.

\section{PENDAHULUAN}

Perkembangan teknologi telah mengalami kemajuan dengan pesat. Hal ini diikuti dengan perkembangan teknologi yang berbasis sistem informasi. Pengolahan dan pemrosesan data akuntansi (sistem informasi akuntansi/SIA) dari secara manual menjadi secara otomatis merupakan salah satu pengaruh dari perkembangan teknologi berbasis sistem informasi tersebut. Perkembangan teknologi berbasis sistem informasi ini akan berpengaruh terhadap sektor perbankan yang sedang melakukan usahanya untuk berpartisipasi dalam pembangunan nasional yang bertujuan untuk meningkatkan kemajuan ekonomi guna meningkatkan kesejahteraan masyarakat. Pesatnya pertumbuhan sektor 
perbankan saat ini akan menimbulkan persaingan antara perusahaan satu dengan yang lainnya. Perusahaan yang mampu bertahan dan berkembang adalah perusahaan yang mampu memanfaatkan perkembangan teknologi dengan maksimal. Adventri (2008) mengemukakan bahwa dalam aktivitas operasionalnya, pihak manajemen suatu perusahaan membutuhkan informasi-informasi yang berkualitas guna menghasilkan keputusan yang tepat dan bermanfaat bagi perusahaan tersebut. Informasi-informasi yang dibutuhkan manajemen tersedia dalam sistem informasi yang dirancang untuk mengatur arus dan pengolahan data akuntansi dalam perusahaan sehingga data keuangan yang ada dapat bermanfaat dan dijadikan sebagai dasar pengambilan keputusan oleh pihak manajemen maupun pihak luar perusahaan.

Sektor perbankan menjalankan usahanya menggunakan sistem informasi untuk mengatasi masalah-masalah yang timbul karena kurangnya keefektifan dalam melakukan pengelolaan transaksi, pengamatan data, pengecekan saldo. PT. BPR Shinta Putra merupakan perusahaan perbankan yang sedang berkembang untuk memajukan perekonomian masyarakat di daerah Kulon Progo. Hal ini terlihat dari banyaknya masyarakat Kulon Progo yang menjadi nasabah PT. BPR Shinta Putra. Pelayanan kepada nasabah menjadi hal yang sangat penting karena langsung berhadapan dengan nasabah sehingga SIA akan memudahkan dalam pelayanan terutama transaksi dengan nasabah. Ketersediaan sistem informasi akuntansi yang memadai sangat dibutuhkan PT. BPR Shinta Putra Pengasih untuk dapat bertahan bahkan berkembang dalam menghadapi persaingan bisnis perbankan yang kian ketat. Selain memerlukan informasi yang akurat dalam pengolahan datanya, sistem informasi juga berguna untuk memudahkan nasabah dalam melakukan transaksi. Berdasarkan sistem informasi yang digunakan maka dapat diketahui manajemen perusahaan tersebut bagus atau tidaknya.

Adventri (2008) mengemukakan bahwa pelatihan dan pendidikan dalam pengembangan sistem pada umumnya diperlukan dan lebih baik jika para anggota tim dilatih sebelumnya. Tentu saja taraf pelatihan harus disesuaikan dengan pengetahuan penggunanya. Sementara itu, Almilia dan Briliantien (2007) mengemukakan bahwa tidak semua sektor perbankan membutuhkan pelatihan 
dalam pengembangan sistem. Sudibyo dan Kuswanto (2011) berpendapat bahwa baik buruknya kinerja dari sebuah sistem informasi dapat dinilai melalui kepuasan pemakai dari sistem informasi akuntansi itu sendiri.

Penelitian yang telah dilakukan Ives dan Olson (1981) dalam Sudibyo dan Kuswanto (2011), menunjukkan terdapat hubungan positif antara partisispasi pemakai dan keberhasilan sistem. Menurut Staples dan Selldon (2004) dalam Amri (2009), salah satu tujuan utama dari penelitian di bidang teknologi informasi adalah untuk membantu tingkat pemakai akhir dan organisasi agar dapat memanfaatkan teknologi informasi secara efektif dan efisien. Suatu riset mengenai sistem informasi kepuasan pengguna dan penggunaan sistem merupakan indikator yang sering digunakan sebagai pengganti (surrogate) untuk mengukur efektivitas atau keberhasilan kinerja suatu sistem informasi. Almilia dan Briliantien (2007) mengemukakan adanya beberapa faktor yang mempengaruhi kinerja sistem informasi akuntansi yang diukur dari dua persepsi yaitu kepuasan pemakai dan pemakaian sistem itu sendiri yaitu dukungan manajemen, kemampuan teknik personal, keterlibatan pemakai sistem, keberadaan program pelatihan, lokasi departemen sistem informasi, formalisasi pengembangan sistem informasi dan ukuran organisasi. Penelitian ini bertujuan untuk mengetahui faktor-faktor yang mempengaruhi kinerja sistem informasi akuntansi pada PT BPR Shinta Putra Pengasih Kulon Progo.

\section{TINJAUAN PUSTAKA DAN PENGEMBANGAN HIPOTESIS}

\section{Sistem Informasi}

Informasi merupakan data yang telah diolah menjadi sebuah bentuk yang bermanfaat bagi penerima informasi tersebut. Informasi bermanfaat dalam pengambilan keputusan di masa sekarang maupun masa datang. Sedangkan sistem adalah suatu rerangka kerja yang terpadu dan mempunyai satu sasaran atau lebih. Sistem dapat diartikan sebagai suatu susunan atau cara. Menurut Anggarsari (2008) sistem informasi adalah suatu rerangka kerja dimana sumberdaya (manusia, komputer) dikoordinasikan untuk mengubah masukan (data) menjadi keluaran (informasi), guna mencapai sasaran perusahaan. 


\section{Sistem Informasi Akuntansi}

Menurut Susanto (2002) sistem informasi akuntansi didefinisikan sebagai kumpulan dari subsistem-subsistem yang saling berhubungan satu sama lain dan bekerja sama secara harmonis untuk mengolah data keuangan menjadi suatu informasi keuangan yang dibutuhkan oleh manajemen dalam proses pengambilan keputusan di bidang keuangan. Sistem informasi akuntansi dirancang untuk memudahkan dalam mengubah data keuangan yang ada menjadi suatu informasi yang bermanfaat yang dapat digunakan dalam pengambilan keputusan baik secara sistem manual maupun sistem komputerisasi. Saat menjalankan sistem informasi akuntansi terdapat beberapa unsur-unsur yang terlibat yang saling berhubungan dalam melaksanakan suatu sistem. Unsur-unsur yang terlibat adalah manusia sebagai pelaksana, perusahaan sebagai objek yang membutuhkan sistem, dan pengolahan data transaksi untuk menghasilkan informasi itu sendiri. Apabila salah satu unsur tersebut tidak berjalan secara optimal maka sistem tersebut tidak akan dapat menghasilkan informasi yang efektif dan berguna bagi manajemen.

\section{Kinerja Sistem Informasi Akuntansi}

Menurut Suyudi (1999) dalam Kurniawan, (2010) kinerja adalah hasil kerja yang dapat dicapai oleh seseorang atau sekelompok orang dalam organisasi sesuai dengan wewenang dan tanggung jawab masing-masing dalam mencapai tujuan organisasi. Kinerja adalah penampilan hasil karya seseorang baik dalam hal kuantitas maupun kualitas dalam suatu organisasi. Kinerja dapat berupa penampilan individu maupun kelompok kerja personel (Amri, 2009).

\section{Program Pelatihan dan Pendidikan bagi Pemakai Berpengaruh terhadap Kinerja Sistem Informasi Akuntansi}

Keberhasilan suatu sistem ditentukan teknologi sistem dan pemakai sistem tersebut. Kegiatan pelatihan dan pendidikan diadakan untuk melatih serta mengembangkan kemampuan pemakai sistem. Selain itu, kegiatan ini juga membangun mental dan rasa percaya diri pemakai sistem dalam menghadapi persaingan di masa kini. Semakin ahli pemakai sistem maka sistem informasi yang dipakai dapat dioptimalkan. Adventri (2008) mengemukakan bahwa pelatihan dan 
pendidikan dalam pengembangan sistem pada umumnya akan diperlukan dan lebih baik jika para anggota tim dilatih sebelumnya. Pelatihan ini juga berguna untuk memperbaiki komunikasi dikalangan anggota.

Nelson (1990) dalam Puspitasari (2007) menyatakan bahwa kesuksesan penggunaan sistem sangat bergantung pada teknologi itu sendiri dan tingkat keahlian individu yang mengoperasikan. Pelatihan ditujukan untuk melatih dan mengembangkan kemampuan pengguna sistem serta dapat membangun rasa percaya diri pengguna sistem sehingga mengantisipasi timbulnya kecemasan dan penolakan dari pengguna terhadap sistem baru. Berdasarkan teori tersebut maka hipotesis dapat ditulis sebagai berikut:

H1: Program pelatihan dan pendidikan bagi pemakai berpengaruh terhadap kinerja sistem informasi akuntansi pada PT. BPR Shinta Putra.

\section{Partisipasi Pemakai Berpengaruh terhadap Kinerja Sistem Informasi} Akuntansi

Penelitian yang dilakukan oleh Tjhai Fung Jen (2002) dalam Amri (2009) membuktikan bahwa semakin sering keterlibatan pemakai akan meningkatkan kinerja sistem informasi dikarenakan ada hubungan antara keterlibatan pemakai dalam proses pengembangan sistem informasi. Adanya partisipasi pemakai merupakan sebuah upaya untuk mencapai kepuasan pemakai agar keberhasilan dalam pengembangan sistem dapat tercapai.

Hasil Penelitian Adventri (2008) menunjukkan bahwa partisipasi pemakai sistem informasi berpengaruh dalam perancangan dan pengembangan sistem informasi. Efektivitas dari sistem informasi dipengaruhi oleh keterlibatan pemakai dalam perancangan dan pengembangan sistem informasi akuntansi dan oleh kualitas dukungan yang diberikan pemakai, salah satunya adalah dengan menggunakan komputer secara efektif. Berdasarkan penjelasan tersebut maka hipotesis dapat disusun sebagai berikut:

H2: Partisipasi pemakai berpengaruh terhadap kinerja sistem informasi akuntansi pada PT. BPR Shinta Putra. 


\section{Kemampuan Teknik Personal Berpengaruh terhadap Kinerja Sistem Informasi Akuntansi}

Keberhasilan sistem tak lepas dari kemampuan teknik penggunanya. Semakin ahli penggunanya maka sistem dapat digunakan secara optimal. Para peneliti mengasumsikan bahwa tingkat pengetahuan komputer pengguna secara langsung dapat mempengaruhi kepuasan. Kemampuan pemakai dapat berupa pengetahuan tentang sistem informasi tersebut, dan keahlian dalam mengekspresikan kebutuhannya dalam sistem informasi. Robbins (2005) dalam Adventri (2008) mengemukakan kemampuan individu mengacu pada kapasitas individu untuk melakukan berbagai tugas dalam pekerjaan. Kemampuan pemakai sistem informasi dalam hal ini, dapat dilihat dari pengetahuan (knowledge), kemampuan (abilities), serta keahlian (skills).

Tjhai Fung Jen (2002) dalam Amri (2009) juga berpendapat bahwa semakin tinggi kemampuan teknik personal akan meningkatkan kinerja sistem informasi akuntansi. Hal ini dikarenakan adanya hubungan yang positif antara kemampuan teknik personal drngan kinerja sistem informasi akuntansi. Berdasarkan teori di atas maka hipotesis dapat disusun sebagai berikut:

H3: Kemampuan teknik personal berpengaruh terhadap kinerja sistem informasi akuntansi PT. BPR Shinta Putra.

\section{Dukungan Manajemen Berpengaruh terhadap Kinerja Sistem Informasi} Akuntansi

Tjhai Fung Jen (2002) dalam Amri (2009) berpendapat bahwa semakin besar dukungan yang diberikan oleh manajemen puncak akan meningkatkan kinerja sistem informasi akuntansi. Dukungan yang diberikan dapat berupa dukungan moral atau dukungan material. Dukungan ini sangat penting dalam keberhasilan semua kegiatan yang berkaitan dengan sistem informasi. Hasil Penelitian Amri (2009) menunjukkan bahwa dukungan manajemen berpengaruh terhadap kinerja sistem informasi akuntansi. Semakin tinggi keterlibatan dukungan manajemen yang diberikan maka akan semakin tinggi pula kinerja sistem informasi akuntansi. Berdasar teori tersebut maka hipotesis dapat ditulis sebagai berikut: 
H4: Dukungan manajemen berpengaruh terhadap kinerja sistem informasi akuntansi pada PT. BPR Shinta Putra.

\section{METODA PENELITIAN}

\section{Populasi dan sampel}

Populasi dalam penelitian ini adalah seluruh karyawan PT. BPR Shinta Putra yang bekerja menggunakan atau mengoperasikan sistem informasi akuntansi. Sampel dalam penelitian ini adalah seluruh karyawan/pemakai sistem informasi akuntansi. Yang dijadikan objek penelitian yaitu PT. BPR Shinta Putra. Jenis data yang digunakan adalah data primer yang diperoleh dengan menggunakan metoda survei langsung kepada pemakai sistem informasi akuntansi melalui pembagian kuesioner.

\section{Definisi Operasional dan Pengukuran Variabel}

\section{Partisipasi Pemakai}

Partisipasi yang dilakukan oleh pemakai berupa intervensi personal yang nyata atau aktivitas pemakai dalam pengembangan sistem yang digolongkan atas tiga tipe yaitu: konsultatif, representatif, dan consensus (Amri, 2009). Instrumen yang digunakan untuk mengukur partisipasi pemakai diadopsi dari Amri (2009). Instrumen ini diukur dengan 6 item pertanyaan menggunakan 6 poin skala Likert. Poin 1 menunjukkan partisipasi pemakai sangat tinggi dan poin 6 menunjukkan partisipasi pemakai sangat rendah.

\section{Program Pelatihan dan Pendidikan}

Program pelatihan dan pendidikan dilakukan untuk meningkatkan produktivitas para karyawan demi memajukan perusahaan.Instrumen yang digunakan untuk mengukur program pelatihan dan pendidikan diambil dari Amri (2009). Instrumen ini diukur dengan 2 items pertanyaan menggunakan 6 poin skala Likert. Poin 1 menunjukkan program pelatihan dan pendidikan bermanfaat dan poin 6 menunjukkan program ini tidak bermanfaat. 


\section{Kemampuan Teknik Personal}

Kemampuan teknik merupakan hal yang wajib dimiliki untuk dapat mendukung dalam pengembangan sistem informasi. Kemampuan ditentukan dari pengalaman dalam menggunakan sistem. Kemampuan teknik personal diukur dengan instrument yang diambil dari Amri (2009). Ada 2 item pertanyaan dengan skala Likert 6. Poin 1 menggambarkan kemampuan baik dan poin 6 menggambarkan kemampuan sangat rendah.

\section{Dukungan manajemen}

Dukungan manajemen merupakan pemahaman manajemen terhadap sistem yang digunakan dan minat kerja serta pengetahuan tentang sistem informasi. Instrumen yang digunakan untuk mengukur variabel ini diambil dari Amri (2009). Instrumen ini diukur dengan 5 item pertanyaan menggunakan 6 poin skala Likert. Poin 1 menunjukkan dukungan manajemen sangat tinggi dan poin 6 menunjukkan dukungan manajemen sangat rendah.

\section{Kinerja Sistem}

Kinerja sistem merupakan suatu hasil yang dicapai para pemakai dalam penggunaan sistem informasi yang efektif dan efisien serta ekonomis. Instrumen yang digunakan untuk mengukur variabel ini diambil dari Anggarsari (2008). Instrumen ini diukur dengan 11 item pertanyaan menggunakan 6 poin skala Likert. Poin 1 menunjukkan kinerja sistem sangat baik dan poin 6 menunjukkan kinerja sistem tidak baik.

\section{Teknik Analisis Data}

\section{Uji Kualitas Data}

Valid tidaknya kuesioner ditentukan dengan membandingkan antara angka korelasi Products moment Pearson (r hitung) dengan $r$ tabel pada level signifikansi 0,05 nilai kritisnya. Jika nilai $\mathrm{r}$ hitung > $\mathrm{r}$ tabel maka pertanyaan dinyatakan valid.Sedangkan jika $\mathrm{r}$ hitung $<\mathrm{r}$ tabel maka pertanyaan dinyatakan tidak valid. 
Sementara itu, suatu konstruk atau variabel dikatakan reliabel jika memberikan nilai cronbach alpha > 0,60 (kurniawati, 2006).

\section{Uji Asumsi Klasik}

\section{a. Uji Normalitas}

Uji normalitas digunakan untuk mengetahui data penelitian berdistribusi normal atau tidak. Uji ini dilakukan dengan melihat Kolmogorov-Smirnov pada SPSS, apabila Asymp. Sig (2-tailed) > 0,05 maka data berdistribusi normal dan sebaliknya (Kurniawati, 2006:14).

\section{b. Uji Multikolinieritas}

Uji multikolinieritas digunakan untuk mendeteksi suatu model regresi terdapat multikolinearitas, uji ini dilakukan dengan melihat nilai variance inflation factor (VIF). Jika variance inflation factor $(\mathrm{VIF})>10$, maka ada multikolinearitas.

\section{c. Uji Heteroskedastisitas}

Uji Heteroskedastisitas dapat diuji dengan menggunakan cara uji Glejser, yaitu dengan meregresikan variabel independen dengan nilai absolut residualnya. Jika Uji Glejser > 0,05 (alpha) maka model tersebut tidak heteroskedastisitas.

\section{d. Uji Autokorelasi}

Salah satu cara yang dapat digunakan untuk mendeteksi ada atau tidaknya autokorelasi yaitu dengan uji Durbin Watson (DW) test. Menurut Sujarweni (2007: 180) pengambilan keputusan ada tidaknya autokorelasi yaitu:

$$
\begin{array}{ll}
\mathrm{d}<\mathrm{DWL} & : \text { ada autokorelasi } \\
(4-\mathrm{DWU})<(4-\mathrm{DWL}) & : \text { tanpa simpulan } \\
\text { DWU }<\mathrm{d}<(4-\mathrm{DWU}) & : \text { tidak ada autokorelasi } \\
\text { DWL }<\mathrm{d}<\text { DWU } & : \text { tanpa simpulan }
\end{array}
$$

\section{Pengujian Hipotesis}

\section{Koefisien Determinasi}

Nilai koefisien determinasi yaitu antara 0 sampai 1 . Nilai yang mendekati 1 berarti variabel-variabel independen memberikan hampir semua informasi yang dibutuhkan untuk memprediksi variasi variabel dependen (Ghozali, 2006 dalam Sawitri, 2011). 


\section{Uji F}

Uji F dilakukan untuk mengetahui pengaruh variabel bebas secara bersamasama terhadap variabel terikat. Dapat dilihat dari taraf signifikansi, jika taraf signifikansinya > 0,05 maka Ha ditolak, artinya tidak ada pengaruh yang signifikan semua variabel bebasnya secara bersama-sama terhadap variabel terikatnya.

\section{Uji t}

Uji t untuk menguji bagaimana pengaruh masing-masing variabel bebasnya sendiri-sendiri terhadap variabel terikatnya. Uji ini dapat dilihat dari taraf signifikansinya, jika taraf signifikansi > 0,05 maka disimpulkan Ha ditolak, artinya tidak ada pengaruh yang signifikan antara variabel bebas terhadap variabel terikat.

\section{Model Penelitian}

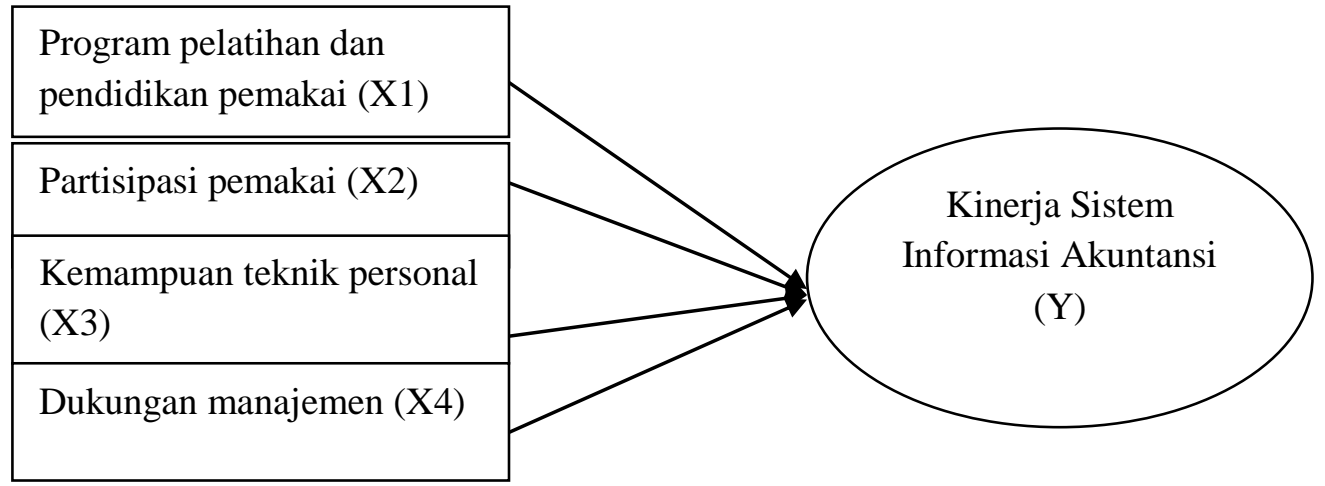

Gambar 1

Model Penelitian

\section{HASIL DAN PEMBAHASAN}

\section{Deskripsi Responden}

Responden dalam penelitian ini adalah karyawan PT. BPR Shinta Putra yang menggunakan sistem informasi akuntansi. Penelitian ini mengambil 35 karyawan yang bekerja di bagian SDM, perencanaan, administrasi dan pelaporan, pemasaran, dan bagian umum. Berdasarkan kuesioner yang kembali dan dapat diolah diketahui bahwa responden dalam penelitian ini mayoritas adalah perempuan, yaitu dengan perbandingan perempuan $74,3 \%$ dan laki-laki $25,7 \%$. Adapun pendidikan terakhir responden mayoritas adalah lulusan S1 yaitu sebesar $62,8 \%$. 
Analisis Data

\section{Hasil Uji Kualitas Data}

Hasil uji validitas menunjukkan semua item pertanyaan dari masing-masing variabel valid, kecuali variabel dukungan manajemen puncak terdapat satu item pertanyaan yang tidak valid sehingga item pertanyaan dihilangkan dan dilakukan pengujian kedua. Hasil pengujian kedua menunjukkan item valid, hal ini terlihat dari semua item bahwa besarnya $r$ hitung $>r$ tabel. Nilai $r$ hitung dapat dilihat dari kolom corrected item total corelation dari hasil SPSS, sedangkan $r$ tabel didapatkan dari degree of freedomf dengan tingkat signifikansi 0,05.

Hasil uji reliabilitas menunjukkan bahwa semua item pertanyaan dari masingmasing variable dinyatakan reliabel karena nilai cronbach alpha pada masingmasing variabel $>0,60$. Sehingga layak untuk dilakukan pengujian selanjutnya.

\section{Uji Asumsi Klasik}

a. Uji Normalitas

Hasil pengujian normalitas data menunjukkan nilai Asymp. Sig pada persamaan regresi menunjukkan nilai signifikansi $0,972>0,05$ maka data residual terdistribusi normal, sehingga model regresi memenuhi asumsi klasik.

b. Uji Multikolinieritas

Hasil uji multikolinieritas menunujkkan nilai variance inflation factor VIF < 10, hal ini mengartikan bahwa tidak ada gejala multikolinieritas sehingga model regresi memenuhi asumsi klasik dan dapat dilakukan pengujian selanjutnya.

c. Uji Heteroskedastisitas

Hasil uji Glejser terlihat tidak ada pengaruh yang signifikan antara variabel independen terhadap absolut residual, sehingga model regresi terbebas dari gejala heteroskedastisitas.

d. Uji Autokorelasi

Hasil uji autokorelasi menunjukkan nilai $\mathrm{dwu}=1,7259, \mathrm{dw}=1,810$, dan 4-dwu= 2,2741 sehingga dwu $<\mathrm{dw}<(4-\mathrm{dwu})$ dan dapat disimpulkan model regresi tidak ada autokorelasi. 


\section{Pengujian Hipotesis}

a. Koefisien Determinasi

Koefisien determinasi yang ditunjukkan dari nilai adjusted $R$-Square sebesar 0,357. Hal ini berarti 35,7\% variabel kinerja sistem informasi dapat dijelaskan oleh keempat variabel independen (dukungan manajemen, program pelatihan dan pendidikan, teknik personal, dan partisipasi pemakai) sedangkan sisanya yaitu $64,3 \%$ dijelaskan oleh variabel lain di luar penelitian ini.

b. Hasil Uji F

Dari uji ANOVA didapat nilai F hitung sebesar 5,723 lebih besar dari F tabel sebesr 2,911 dengan probabilitas signifikansi 0,002. Probabilitas signifikansi tersebut lebih kecil dari 0,05, maka variabel independen secara simultan berpengaruh terhadap variabel kinerja sistem informasi akuntansi.

c. Hasil Uji t

Tabel 1

Hasil Uji t (t-test)

\begin{tabular}{|c|c|c|c|c|c|}
\hline $\begin{array}{c}\text { Varibel } \\
\text { Independen }\end{array}$ & $\begin{array}{c}\text { Variabel } \\
\text { Dependen }\end{array}$ & $a$ & T Hitung & Sig & Keterangan \\
\hline Program Pelatihan & \multirow{4}{*}{ Kinerja SIA } & 0,05 & 1,574 & 0,126 & H1 Ditolak \\
\hline Partisipasi Pemakai & & 0,05 & 2,548 & 0,016 & H2 Diterima \\
\hline Teknik Personal & & 0,05 & 2,095 & 0,045 & H3 Diterima \\
\hline Manajemen Puncak & & 0,05 & $-0,841$ & 0,407 & H4 Ditolak \\
\hline
\end{tabular}

Sumber: Data primer, diolah (2014)

\section{Hipotesis Pertama}

Berdasar hasil pengujian hipotesis pertama menunjukkan bahwa program pelatihan dan pendidikan tidak berpengaruh terhadap kinerja sistem informasi akuntansi. Hal ini dapat terlihat pada tingkat signifikansi yaitu 0,407 >0,05. Hasil ini mendukung penelitian yang dilakukan Amri (2009) yang menyebutkan bahwa program pelatihan tidak meningkatkan kinerja sistem informasi karena sebagian besar responden yang ia teliti telah memperoleh keahlian komputer melalui informal job training. Artinya tanpa mengikuti program pelatihan dari perusahaan, para pemakai sistem dapat meningkatkan kemampuan dalam menggunakan sistem. Perbedaan hasil penelitian ini dengan penelitian terdahulu kemungkinan karena 
perbedaan sampel penelitian dimana beberapa peneliti terdahulu menggunakan sampel dari beberapa perusahaan yang sejenis, sedangkan penulis hanya menggunakan sampel dari satu perusahaan saja.

\section{Hipotesis Kedua}

Berdasar hasil pengujian hipotesis kedua menunjukkan bahwa partisipasi pemakai berpengaruh terhadap kinerja sistem informasi akuntansi. Hal ini dapat terlihat pada tingkat signifikansi 0,016 <0,05. Hasil ini mendukung penelitian yang dilakukan oleh Adventri (2008) dan Setiani (2008). Semakin besar partisipasi pemakai maka semakin bagus kinerja sistem informasi akuntansi yang ada. Berdasar hasil kuesioner penelitian, secara umum responden menyatakan tingkat partisipasi pemakai cukup tinggi dalam penggunaan system informasi akuntansi.

\section{Hipotesis Ketiga}

Berdasar hasil pengujian hipotesis ketiga menunjukkan bahwa kemampuan teknik personal berpengaruh terhadap kinerja sistem informasi akuntansi. Hal ini dapat terlihat pada tingkat signifikansi $0,045<0,05$, yang berarti para pemakai sistem informasi akuntansi pada PT. BPR Shinta Putra memiliki kemampuan teknik yang tinggi. Berdasar hasil kuesioner menunjukkan bahwa para pemakai sistem informasi pada PT. BPR Shinta Putra sudah mempelajari sistem informasi semenjak masih duduk dibangku sekolah dan sebagian besar telah memiliki kemampuan spesialis yang meliputi teknik desain sistem. Hasil penelitian ini mendukung penelitian yang dilakukan Amri (2010). Kemampuan teknik pengguna sistem informasi sangatlah dalam perencanaan dan pengembangan sistem informasi akuntansi.

\section{Hipotesis Keempat}

Berdasar hasil pengujian hipotesis keempat menunjukkan bahwa dukungan manajemen tidak berpengaruh terhadap kinerja sistem informasi akuntansi. Hal ini dapat terlihat pada tingkat signifikansi di atas $0,126>0,05$. Tidak berpengaruhnya variabel dukungan manajemen terhadap kinerja sistem informasi disebabkan kurangnya perhatian manajemen puncak terhadap penggunaan sistem informasi 
serta kurang aktifnya manajemen puncak dalam pengembangan sistem informasi. Perbedaan hasil penelitian ini dengan penelitian terdahulu terjadi karena beberapa peneliti terdahulu menggunakan sampel dari beberapa perusahaan yang sejenis, sedangkan penulis hanya menggunakan sampel dari satu perusahaan saja.

\section{SIMPULAN, KETERBATASAN, DAN SARAN}

Simpulan dalam penelitian ini sebagai berikut:

1. Program pelatihan dan pendidikan tidak berpengaruh terhadap kinerja sistem informasi akuntansi.

2. Partisipasi pemakai berpengaruh terhadap kinerja sisitem informasi akuntansi.

3. Kemampuan teknik personal berpengaruh terhadap kinerja sistem informasi akuntansi.

4. Dukungan manajemen tidak berpengaruh terhadap kinerja sistem informasi akuntansi.

Keterbatasan yang ada dalam penelitian ini adalah sebagai berikut:

1. Penulis hanya menggunakan empat variabel independen dalam mempengaruhi kinerja sistem informasi akuntansi, yaitu dukungan manajemen, program pelatihan dan pendidikan, partisipasi pemakai, dan teknik personal. Masih banyak faktor-faktor lain yang dapat digunakan.

2. Penulis menyadari bahwa jumlah sampel dalam penelitian ini relatif sedikit, hanya berjumlah 35 responden dan hanya melibatkan satu perusahaan saja, yaitu PT. BPR Shinta Putra, sebaiknya penelitian selanjutnya melibatkan beberapa sampel yang sejenis sehingga diharapkan hasil yang diperoleh akan lebih mempresentasikan kinerja sistem informasi akuntansi.

3. Metoda pengumpulan data dengan menggunakan metoda kuisioner memiliki keterbatasan berupa lemahnya kontrol terhadap keakuratan jawaban responden karena kemungkinan responden tidak menjawab dengan kedaaan yang sesungguhnya.

Berdasar simpulan dan keterbatasan yang ada, maka saran yang dapat diberikan bagi penelitian selanjutnya adalah sebagai berikut: 
1. Penambahan variabel bebas yang lain, tidak hanya terbatas pada variabel dukungan manajemen, program pelatihan dan pendidikan, partisipasi pemakai, dan teknik personal saja.

2. Peneliti selanjutnya diharapkan melakukan pemilihan waktu yang tepat ketika menyebar kuesioner, hal itu untuk menghindari tidak kembalinya kuesioner.

3. Penambahkan metoda wawancara dalam upaya pengumpulan data untuk menghindari kemungkinan responden yang tidak objektif dalam mengisi kuesioner.

\section{DAFTAR PUSTAKA}

Adventri, Beriyaman. 2008. Analisis Faktor-faktor yang Mempengaruhi Kinerja Sistem Informasi Akuntansi, Universitas Widyatama [Online]. Didapatkan: http://repository.widyatama.ac.id [9 Agustus 2008].

Almilia, Luciana Spica dan Irmaya Briliantien. 2007. Faktor-faktor yang Mempengaruhi Kinerja Sistem Informasi Akuntansi pada Bank Umum Pemerintah di Wilayah Surabaya dan Sidoarjo [Online]. Didapatkan: http://spicaalmilia.wordpress.com [2 Maret 2007].

Amri, Faisal. 2009. Analisis Faktor-faktor yang Mempengaruhi Kinerja Sistem Informasi Akuntansi (Studi Kasus pada PT. Coca-cola Bottling Indonesia). Skripsi. Medan: Universitas Sumatera Utara.

Anggarsari, Dwirini. 2008. Pengaruh Partisipasi dan Kepuasan Pemakai terhadap Kinerja Sistem Informasi. Skripsi. Yogyakarta: Universitas Islam Indonesia.

Jogiyanto. 2002. Sistem Informasi Keperilakuan. Yogyakarta: Penerbit Andi.

Kurniawan, Rahayu. 2010. Pengembangan Kompetensi SDM dan Bantuan Modal Usaha Pengaruhnya terhadap Kinerja Usaha Mikro Kecil Menengah monel dikabupaten Jepara. Skripsi. Semarang: Universitas Negeri Semarang.

Kurniawati, Indah. 2006. Mengolah Data Statistik dengan SPSS 11.5. Yogyakarta: Universitas Ahmad Dahlan. 
Priyatno, Duwi. 2012. Cara Kilat Belajar Analisis Data dengan SPSS 20. Yogyakarta: Penerbit Andi.

Puspitasari, Iin. 2007. Analisis Faktor-faktor yang Mempengaruhi Kinerja Sistem Akuntansi Pasar Swalayan Ada - Semarang. Tesis. Semarang: Universitas Diponegoro.

Sawitri, R.A. Adi Puspa. 2011. Pengaruh Motivasi, Komitmen Organisasi, dan Budaya Organisasi terhadap Kinerja Pegawai (Studi Empiris pada Perum Perhutani Unit 1 Jawa Tengah). Skripsi. Semarang: Universitas Diponegoro.

Setiani, Kartika Oktariza. 2008. Pengaruh Dukungan manajemen dan Partisipasi Pengguna terhadap Kepuasan Pengguna Sistem Informasi Akuntansi pada PT. Telekomunikasi Tbk di Surabaya. Skripsi. Surabaya: STIE Perbanas.

Soegiharto. 2001. "Influence Factors Affecting the Performance of Accounting Information System”. Gajah Mada International Journal of Business. Vol III No.2.

Sudibyo, Sukemi Kamto dan Hedy Kuswanto. 2011. Analisis Faktor-faktor yang Mempengaruhi Kinerja Sistem Informasi Akuntansi pada PT. BPR Weleri Makmur Jawa Tengah.

Sujarweni, V. Wiratna. 2007. Panduan Mudah Menggunakan SPSS dan Contoh Penelitian Bidang Ekonomi. Yogyakarta: Ardana Media.

Susanto, Azhar. 2002. Sistem Informasi Manajemen. Konsep dan Pengembangannya. Edisi Indonesia Kedua. Bandung: Lingga Jaya.

Tejokusumo, Prito. 2009. Analisis Faktor-faktor yang Mempengaruhi Kinerja Sistem Informasi Akuntansi pada PD. BPR Bank Pasar Surakarta. Surakarta: Universitas Muhammadiyah Surakarta. 